\title{
Introduction
}

Esophageal atresia (EA) with or without tracheoesophageal fistula (TEF) is a rare anatomical anomaly, with a prevalence of 2.55 per 10,000 pregnancies in Europe [1]. Advancements in surgery and modern intensive care have led to survival rates up to $93-95 \%$ in dedicated centers, and more children nowadays reach adulthood $[2,3]$.

After surgical repair, many EA patients experience gastroesophageal reflux (GER)[4-8]. If untreated, chronic GER may lead to esophagitis, anastomotic strictures, metaplastic epithelial changes (gastric metaplasia or intestinal metaplasia) and esophageal adenocarcinoma (EAC). When squamous mucosa in the distal esophagus is damaged, usually by GER, it is replaced by metaplastic columnar mucosa, so-called Barrett's esophagus (BE). A study has suggested that metaplasia is found in about $42.1 \%$ of EA patients[9]. In case intestinal metaplasia is present in the metaplastic columnar mucosa, BE becomes an important risk factor for developing esophageal adenocarcinoma (EAC), with an estimated incidence rate of $0.5 \%$ per year during follow-up [10]. In the general population, $B E$ is reported in $1.6 \%$ of adults and is predominantly diagnosed in middle-aged white males[11]. It is suggested that the prevalence of BE in EA patients is higher and that it occurs at a much younger age[7]. Cancer in the upper gastrointestinal tract in EA patients has been described in ten cases, of which 8 were esophageal carcinoma (Table 2) and 2 squamous cell carcinoma not related to the native esophagus (related to the lung and to a subcutaneous skin tube reconstruction)[12-18].

Given the high prevalence of $\mathrm{BE}$, the early development of esophageal cancer, and possible absence of alarm symptoms in EA patients, surveillance programs seems warranted. Prospective long-term follow-up cohort studies, including endoscopic data of adult EA patients, are limited and guidelines for follow-up are lacking. The aim of this review is to give an overview of the prevalence of esophagitis, BE and esophageal cancer in EA patients and outline suggestions for future research.

\section{Gastroesophageal reflux}

Gastroesophageal reflux disease (GERD) is considered a motility disorder, with transient lower esophageal sphincter relaxations as its main underlying mechanism in healthy premature infants, healthy adults, GERD patients and EA patients (shortly after primary anastomosis and in adulthood)[19]. In EA patients several anatomic and functional causes can explain the increased occurrence of GER.

First, by pulling the distal esophagus more cranial during atresia repair the lower esophageal sphincter is displaced, resulting in sphincter incompetence and an increase in retrograde movements of gastric contents into the esophagus. The altered angle of His of the stomach fails to prevent GER[20, 21]. Second, surgical injury to the vagal nerve leads to dysmotility, and despite careful connection of the different muscle layers the esophageal peristaltic wave is disrupted at the anastomosis[19, 20]. Third, disturbed motility seems to be present before atresia repair as a result of deficient extrinsic and intrinsic innervation[19, 20]. And last, delayed gastric emptying in EA patients and upper airway obstruction in EA patients with tracheomalacia or tracheal stenosis[19, 20]. 
The reported prevalence of GER in EA patients after neonatal repair ranges from 32.8-54.2\% during infancy and childhood, and from 5.9-66.7\% during adolescence and adulthood (Table 1). These wide ranges are probably explained by the different definitions used. A recent systematic review on long-term problems in EA patients found a high prevalence of GER, based on GER symptoms, of $40.2 \%$ compared to $10-20 \%$ in the general adult Western population[22, 23]. Typical symptoms of GER are heartburn and acid regurgitation, which are reported by $7.7-27 \%$ and $6.3-16 \%$, respectively, of the general Western population[23]. In EA patients, the prevalence of these symptoms ranges from $14-38 \%$ and $7-34 \%$, respectively[24, 25]. Dysphagia is present in 50.3\% of the patients[22]. GER symptoms are not well correlated with the severity of esophageal damage: up to two thirds of the patients with GER-related symptoms do not have mucosal erosions[26]. Most EA patients do not recognize GER symptoms as troublesome, as they have had these for years, resulting in chronic esophageal injury like erosions, ulcerations, anastomotic strictures, $\mathrm{BE}$ and eventually EAC.

The gold standard for diagnosing GER is ambulatory $\mathrm{pH}$ monitoring, completed with impedance. During $\mathrm{pH}$ monitoring acid reflux is measured, while esophageal impedance can also identify non-acid reflux. At endoscopy typical reflux-induced erosions can be observed. However, as mentioned above, not all patients with GER have mucosal damage, resulting in a low sensitivity of endoscopy as diagnostic tool for GER [26, 27]. Also esophageal biopsies, for assessment of histological changes and number of eosinophils, have not been proven to be useful, because of their low sensitivity and specificity and overlap with eosinophilic esophagitis and various other esophageal diseases (eosinophilic gastrointestinal diseases, celiac disease, drug hypersensitivity and infection) [27, 28]. The basal zone normally compromises no more than $15 \%$ of the total epithelial thickness, the papillae reach up till two thirds of the normal epithelium, and the maximum number of eosinophils in a normal esophageal biopsy specimen is 15 per high-power field [28, 29]. Eosinophilic esophagitis is characterized by eosinophilia, eosinophilic microabscesses, degranulated eosinophila, basal cell hyperplasia, elongated rete pegs and dilated intercellular spaces, but also in GERD patients and even in healthy individuals basal cell hyperplasia, elongated rete pegs and eosinophilia can be found[30]. Therefore histological assessment is often not conclusive to discriminate between the various esophageal diseases[27].

Treatment options for GER are lifestyle modification, acid suppression and surgery. In view of the high occurrence of (severe) GER in EA patients, most newborns with EA receive medical therapy directly after birth. Medical treatment is often successful by reducing gastrointestinal and respiratory symptoms, but anti-reflux surgery, such as Nissen fundoplication, is still needed in up to $44 \%$ of cases (Table 1)[31]. The wrap fails in many patients. A review from 2013 reported a redo-fundoplication of 18\% in EA patients, a much higher percentage than the $7 \%$ of GER patients in the general population[20]. Another study found an ever higher percentage of redo-Nissen procedures, i.e. 25\% [32]. The modified anatomy in EA patients and the persistent dysmotility after medical or surgical anti-GERD treatment may explain the high occurrence of wrap failures[20,33].

Abnormal reflux of gastric contents into the esophagus (and beyond) can cause serious esophageal problems (inflammation, erosions, ulcerations, anastomotic strictures, BE and EAC) and pulmonary problems (asthmatic complaints, inflammation and respiratory distress of apparent life-threatening events (ALTE)). The disturbed 
esophageal motility in EA patients reduces acid clearance and increases the adverse effects of GER in this population. Early diagnosis and treatment of GER in EA patients may influence the onset of GER-related complications.

\section{Esophagitis}

Chronic GER may lead to esophagitis with mucosal breaks, especially when untreated. Upper endoscopy is the most sensitive diagnostic tool for assessment of GER-related mucosal injury. During upper endoscopy, esophagitis is classified using the Los Angeles Classification[34]. For histological examination, the Ismail-criteria have long been considered one of the most reliable criteria for diagnosing reflux esophagitis and these are still used[29]. Although histology can be useful to assess the individual therapeutic response in GERD, routine biopsies cannot be recommended as a diagnostic tool for GERD as the correlation between histological findings and GERD in the absence of mucosal lesions is poor[27].

In EA patients, the prevalence of esophagitis observed during endoscopy is considerably higher than that in the general population: $25.1 \%$ vs. $12-15 \%$ (Table 1)[35, 36]. An endoscopic diagnosis of erosive esophagitis is made in $31.5 \%$ of the infants and children with EA, with histology revealing moderate to severe esophagitis in 8.5\% (Table 1). In adolescents and adults with EA, esophagitis is observed during endoscopic and histological evaluation in $26.4 \%$ and $20 \%$, respectively (Table 1). A recent systematic review found a prevalence of histological esophagitis of $56.5 \%$ in EA patients [22]. This can hardly be interpreted as mild inflammation, as findings included minimal basal hyperplasia, subtle reactive changes and slight amounts of lymphocytic, eosinophilic and neutrophilic infiltration in the epithelium, which are also present in healthy individuals $[27,30]$.

\section{Barrett's esophagus}

The diagnosis $\mathrm{BE}$ is made if normal squamous epithelium of the distal esophagus has been replaced by columnar mucosa[10, 37, 38]. Three types of esophageal metaplastic columnar epithelium are distinguished: gastric fundic type epithelium (surface mucus, parietal and chief cells), gastric cardiac type epithelium (mucus secreting cells), and intestinal type epithelium (goblet cells)[39]. Intestinal metaplasia is the most biologically unstable type of metaplastic columnar epithelium with the greatest risk of neoplastic progression through dysplasia to adenocarcinoma[38]. The annual incidence of EAC in BE patients, defined as the presence of columnar-lined esophagus with intestinal metaplasia, is $0.5 \%[10]$. Whether gastric metaplasia (fundic or cardiac type epithelium) is associated with malignant transformation remains unclear[40-43]. Importantly, the definition of BE differs between guidelines in respect of whether or not intestinal metaplasia is present [10, 37, 38].

The estimated prevalence of $\mathrm{BE}$ in the general population is 1.6\%[11]. In EA patients, the prevalence of $\mathrm{BE}$ varies between $0-12.5 \%$ and that of gastric metaplasia between 0-40.9\% (Table 1). The great variety in BE prevalence in EA patients can be ascribed to different definitions used. It should be noted that in several studies gastric metaplasia without intestinal metaplasia also is defined as BE. This illustrates the importance of using a uniform working definition of $\mathrm{BE}$, so as to prevent overdiagnosis and overtreatment. While in the general population BE patients are usually middle-aged white males, in EA patients BE is diagnosed at a remarkably younger age. In a study from Taylor 
et al., BE was diagnosed in 7/62 (11.3\%) patients with a median age of 37 years (range 21-43 years)[7]. There is some evidence that EA patients with TEF recurrence, long gap EA, esophageal stricture resection in childhood, esophageal stricture present in adulthood, severe reflux symptoms, and age above 30 years are at increased risk for developing $\operatorname{BE}[6,7]$.

To detect BE it is important to identify landmarks such as the Z-line (transition line of squamous to columnar epithelium) and the gastro-esophageal junction (GEJ)[37]. Normally the Z-line corresponds to the GEJ and is in line with the diaphragm. After EA repair, especially after a gastric pull-up, the GEJ is located proximal of the diaphragm. This modified anatomy may complicate landmark recognition.

The purpose of reducing acid exposure in BE is to prevent development of high-grade dysplasia and EAC. Acid suppression drugs are prescribed in almost all BE patients for chemoprevention and symptom control. Anti-reflux surgery is not superior to medical therapy to prevent malignant progression of $B E[10,38]$. Moreover, it does not fully protect GERD patients against BE development. Sistonen et al. found that $40 \%$ of the EA patients with prior antireflux surgery developed esophageal gastric or intestinal metaplasia[6].

Endoscopic resection with or without ablation therapy can be offered with curative intent when BE with high-grade dysplasia or early stage esophageal cancer is detected. The treatment of choice depends on the tumor stage, patient's age, comorbidity, preferences and local expertise[37, 38, 44-46].

\section{Esophageal cancer}

The two commonest types of esophageal cancer are EAC deriving from the columnar mucosa and esophageal squamous cell carcinoma (ESCC) originating from the squamous mucosa. Dysphagia is often the first symptom of esophageal cancer. However, dysphagia is common in EA patients (prevalence 48-72\%) and patients therefore are not necessarily alarmed by this symptom[5]. Because of the association between BE and EAC, EA patients with prolonged GER and BE may have an increased risk for malignant progression.

Over the last decades, survival of EA patients has increased and many more patients reach adulthood. Long-term follow-up studies in adult EA patients are scarce. To date 8 cases of esophageal cancer in adult EA patients have been reported: 3 EAC and 5 ESCC (Table 2)[12-16]. The tumors were mainly located in the middle esophagus and diagnosed at a young age (median 38 years; range 20-46 years). A few articles about cancer risk in this population have been published, but large follow-up cohort studies in patients throughout adolescence and adult life are needed for proper risk assessment and stratification. Two Scandinavian studies both found 3 cases of cancer (no esophageal cancer) in a cohort of 870 and a cohort of 272 EA patients, respectively[47, 48]. The esophageal cancer prevalence was not higher than in the general population, but the median follow-up in both studies was only 16 and 35 years, respectively. In an Australian cohort of 309 adult EA patients (age $\geq 40$ years), of whom 76 underwent endoscopic screening, 4 ESCC were found[13]. However, cause of death or long-term outcome was not known in 120 of the 309 patients (38.8\%). The cumulative incidence of ESCC in EA adults above 40 years of age was fifty-fold higher than that in the general population. 
These findings should be interpreted with caution, however, because of the small power of the studies and the relatively short follow-up period. To date the relevant literature has reported more ESCC than EAC. Possible reasons are the fact that EA patients have a higher risk of developing ESCC than EAC, publication bias, or a relatively short follow-up in adulthood. With regard to the latter, EAC derived from BE could develop on a longer term than ESCC. The follow-up period in most of the studies including EA patients is relatively short.

\section{Screening and surveillance}

As described above, EA patients appear to have a higher prevalence of $\mathrm{BE}$ at a younger age compared to the general population. Due to the poor prognosis of patients with esophageal cancer, early diagnosis is of utmost importance to make curative and less invasive treatment still feasible. For recommendations about endoscopic screening and surveillance of BE in EA patients, presence of intestinal metaplasia should be taken into account as gastric type mucosa in columnar-lined esophagus is of less clinical importance in terms of the likelihood of malignant transformation.

To date guidelines on esophageal follow-up in EA patients are lacking. Several screening strategies have been suggested as clinical screening in all patients aged 15-25 years, with endoscopy performed if any GER symptoms are present [7]. Another study suggested endoscopic surveillance at the ages of 15, 30, 40, 50 and 60 years, with intensification of this protocol if pathological observations are made: yearly in case of BE and 5-yearly in the presence of esophagitis, gastric metaplasia, severe esophageal strictures, recurrent TEF, severe GER symptoms, or the need for continuous anti-GERD medication[5]. Other endoscopy protocols suggest screening in all adults, i.e. from the age of 30 years for patients with significant primary surgery complications; from the age of 20 years regardless of symptoms (5-yearly until the age of 30 years, 3-yearly until the age of 40 years, 2-yearly after 40 year of age); and screening once before adulthood with surveillance through adulthood with 5 to 10 year intervals (3-yearly in case of BE or twice a year with dysplasia) $[6,9,13,49]$.

\section{Future prospects}

Large cohort studies with long follow up focusing on the development of BE and esophageal cancer in EA patients are scarce. A few suggestions for endoscopic surveillance programs in this population have been put forward, but none of these strategies has been validated in a population-based follow-up study. Screening all adult EA patients is labor-intensive. Moreover, the inconvenience and burden of repeated endoscopies for the patients should not be underestimated. Future large prospective follow-up cohort studies are needed to define the actual BE and cancer risk in (adult) EA patients. In this regard it is important to identify pivotal risk factors, including genetic predisposition, to focus and intensify surveillance in those patients at true risk for developing EAC or ESCC, rendering surveillance program more cost-effective and less inconvenient to EA patients overall. 


\section{Legends of tables}

Table 1: Literature reports on the prevalence of GER symptoms, pH-measurements, esophagitis, gastric metaplasia, Barrett's esophagus and fundoplication surgery in EA patients: children(A), adults $(B)$ and both children and adults $(C)$.

EA: esophageal atresia, GER: gastroesophageal reflux, GERD: gastroesophageal reflux disease, NR: not (clearly) reported \# To exclude selection bias, these numbers are not used to calculate the total prevalence of the features, see below the different reasons.

${ }^{1}$ GERD diagnosis defined as: fundoplication surgery performed, $\mathrm{pH}$-measurement positive or endoscopic esophagitis (according to the ACG Guidelines[27]).

${ }^{2}$ No official classification used for endoscopic grading of esophagitis.

${ }^{3}$ Histological diagnosis of 3 biopsies was unspecified.

${ }^{4}$ Fundoplication surgery and $\mathrm{pH}$-measurement.

${ }^{5}$ Fundoplication surgery, $\mathrm{pH}$ measurement, and histological esophagitis (moderate-severe).

${ }^{6}$ Biopsies ( $\left.n=12\right)$ taken in presence of endoscopic abnormalities: Barrett's esophagus $(n=10)$ and/or esophagitis ( $\left.n=6\right)$.

${ }^{7}$ Biopsies ( $\left.n=17\right)$ taken in presence of esophagitis and/or Barrett's epithelium $(n=8)$ or normal mucosa $(n=9)$.

${ }^{8}$ Patients with a history of fundoplication surgery or severe/obvious symptoms were excluded from this study.

Table 2: Reported esophageal cancer in EA patients $(n=8)$.

BE: Barrett's esophagus, EA: esophageal atresia, EAC: esophageal adenocarcinoma, ESCC: esophageal squamous cell carcinoma, GEJ: gastroesophageal junction, GER: gastroesophageal reflux, GERD: gastroesophageal reflux disease, TEF: tracheo esophageal fistula 


\section{References}

1. EUROCAT, EUROCAT Website Database http://www.eurocatnetwork.eu/ACCESSPREVALENCEDATA/PrevalenceTables 2012.

2. Wang, B., et al., A nationwide analysis of clinical outcomes among newborns with esophageal atresia and tracheoesophageal fistulas in the United States. J Surg Res. 2014; 190: 604-12.

3. Sulkowski, J.P., et al., Morbidity and mortality in patients with esophageal atresia. Surgery. 2014; 156: 483-91.

4. Deurloo, J.A., et al., Esophageal atresia: historical evolution of management and results in 371 patients. Ann Thorac Surg. 2002; 73: 267-72.

5. Rintala, R.J. and M.P. Pakarinen, Long-term outcome of esophageal anastomosis. Eur J Pediatr Surg. 2013; 23: 219-25.

6. Sistonen, S.J., et al., Esophageal morbidity and function in adults with repaired esophageal atresia with tracheoesophageal fistula: a population-based long-term follow-up. Ann Surg. 2010; 251: 1167-73.

7. Taylor, A.C., et al., Gastroesophageal reflux and related pathology in adults who were born with esophageal atresia: a long-term follow-up study. Clin Gastroenterol Hepatol. 2007; 5: 702-6.

8. Biller, J.A., et al., Long-term evaluation of esophageal and pulmonary function in patients with repaired esophageal atresia and tracheoesophageal fistula. Dig Dis Sci. 1987; 32: 98590.

9. Schneider, A., L. Michaud, and F. Gottrand, Esophageal atresia: metaplasia, Barrett. Dis Esophagus. 2013; 26: p. 425-7.

10. American Gastroenterological, A., et al., American Gastroenterological Association medical position statement on the management of Barrett's esophagus. Gastroenterology. 2011; 140: 1084-91.

11. Ronkainen, J., et al., Prevalence of Barrett's esophagus in the general population: an endoscopic study. Gastroenterology. 2005; 129: 1825-31.

12. Deurloo, J.A., et al., Esophageal squamous cell carcinoma 38 years after primary repair of esophageal atresia. J Pediatr Surg. 2001; 36: 629-30.

13. Jayasekera, C.S., et al., Cluster of 4 cases of esophageal squamous cell cancer developing in adults with surgically corrected esophageal atresia--time for screening to start. J Pediatr Surg. 2012; 47: 646-51.

14. Adzick, N.S., et al., Esophageal adenocarcinoma 20 years after esophageal atresia repair. J Pediatr Surg. 1989; 24: 741-4.

15. Alfaro, L., et al., Are patients who have had a tracheoesophageal fistula repair during infancy at risk for esophageal adenocarcinoma during adulthood? J Pediatr Surg. 2005; 40: 719-20.

16. Pultrum, B.B., et al., Development of an adenocarcinoma of the esophagus 22 years after primary repair of a congenital atresia. J Pediatr Surg. 2005; 40: e1-4.

17. Esquibies, A.E., et al., Pulmonary squamous cell carcinoma associated with repaired congenital tracheoesophageal fistula and esophageal atresia. Pediatric Pulmonology. 2010; 45: 202-204.

18. LaQuaglia, M.P., M. Gray, and S.R. Schuster, Esophageal atresia and ante-thoracic skin tube esophageal conduits: squamous cell carcinoma in the conduit 44 years following surgery. $J$ Pediatr Surg. 1987; 22: 44-7.

19. van Wijk, M., et al., Evaluation of gastroesophageal function and mechanisms underlying gastroesophageal reflux in infants and adults born with esophageal atresia. J Pediatr Surg. 2013; 48: 2496-505.

20. Tovar, J.A. and A.C. Fragoso, Gastroesophageal Reflux after Repair of Esophageal Atresia. Eur J Pediatr Surg. 2013; 23: 175-181. 
21. Wheatley, M.J., A.G. Coran, and J.R. Wesley, Efficacy of the Nissen fundoplication in the management of gastroesophageal reflux following esophageal atresia repair. J Pediatr Surg. 1993; 28: 53-5.

22. Connor, M.J., et al., Esophageal atresia and transitional care-step 1: a systematic review and meta-analysis of the literature to define the prevalence of chronic long-term problems. Am J Surg. 2015; 209: 747-759.

23. Dent, J., et al., Epidemiology of gastro-oesophageal reflux disease: a systematic review. Gut. 2005; 54: 710-7.

24. Gatzinsky, V., et al., Added Value of pH Multichannel Intraluminal Impedance in Adults Operated for Esophageal Atresia. Eur J Pediatr Surg. 2015.

25. Tomaselli, V., et al., Long-term evaluation of esophageal function in patients treated at birth for esophageal atresia. Pediatr Surg Int. 2003; 19: 40-3.

26. Hershcovici, T. and R. Fass, Nonerosive Reflux Disease (NERD) - An Update. J Neurogastroenterol Motil. 2010; 16: 8-21.

27. Katz, P.O., L.B. Gerson, and M.F. Vela, Guidelines for the diagnosis and management of gastroesophageal reflux disease. Am J Gastroenterol, 2013. 108(3): p. 308-28; quiz 329.

28. Liacouras, C.A., et al., Eosinophilic esophagitis: updated consensus recommendations for children and adults. J Allergy Clin Immunol. 2011; 128: 3-20 e6; quiz 21-2.

29. Ismail-Beigi, F., P.F. Horton, and C.E. Pope, 2nd, Histological consequences of gastroesophageal reflux in man. Gastroenterology. 1970; 58: 163-74.

30. Schindlbeck, N.E., et al., Diagnostic value of histology in non-erosive gastro-oesophageal reflux disease. Gut. 1996; 39: 151-4.

31. Shawyer, A.C., et al., The management of postoperative reflux in congenital esophageal atresia-tracheoesophageal fistula: a systematic review. Pediatr Surg Int. 2014; 30: 987-96.

32. Bergmeijer, J.H., D. Tibboel, and F.W. Hazebroek, Nissen fundoplication in the management of gastroesophageal reflux occurring after repair of esophageal atresia. J Pediatr Surg. 2000; 35: 573-6.

33. Godoy, J., et al., Esophageal motor dysfunction persists in children after surgical cure of reflux: an ambulatory manometric study. J Pediatr Surg. 2001; 36: 1405-11.

34. Lundell, L.R., et al., Endoscopic assessment of oesophagitis: clinical and functional correlates and further validation of the Los Angeles classification. Gut. 1999; 45: 172-80.

35. Zagari, R.M., et al., Gastro-oesophageal reflux symptoms, oesophagitis and Barrett's oesophagus in the general population: the Loiano-Monghidoro study. Gut. 2008; 57: 1354-9.

36. Ronkainen, J., et al., High prevalence of gastroesophageal reflux symptoms and esophagitis with or without symptoms in the general adult Swedish population: a Kalixanda study report. Scand J Gastroenterol. 2005; 40: 275-85.

37. Wang, K.K., R.E. Sampliner, and G. Practice Parameters Committee of the American College of, Updated guidelines 2008 for the diagnosis, surveillance and therapy of Barrett's esophagus. Am J Gastroenterol. 2008; 103: 788-97.

38. Fitzgerald, R.C., et al., British Society of Gastroenterology guidelines on the diagnosis and management of Barrett's oesophagus. Gut. 2014; 63: 7-42.

39. Paull, A., et al., The histologic spectrum of Barrett's esophagus. N Engl J Med. 1976; 295: 47680.

40. Riddell, R.H. and R.D. Odze, Definition of Barrett's esophagus: time for a rethink--is intestinal metaplasia dead? Am J Gastroenterol. 2009; 104: 2588-94.

41. Lindahl, H., R. Rintala, and H. Sariola, Chronic esophagitis and gastric metaplasia are frequent late complications of esophageal atresia. J Pediatr Surg. 1993; 28: 1178-80.

42. Somppi, E., et al., Outcome of patients operated on for esophageal atresia: 30 years' experience. J Pediatr Surg. 1998; 33: 1341-6.

43. Deurloo, J.A., et al., Esophagitis and Barrett esophagus after correction of esophageal atresia. J Pediatr Surg. 2005; 40: 1227-31. 
44. Allum, W.H., et al., Guidelines for the management of oesophageal and gastric cancer. Gut. 2011; 60: 1449-72.

45. Lightdale, C.J., Esophageal cancer. American College of Gastroenterology. Am J Gastroenterol. 1999; 94: 20-9.

46. Didden, P. and A.D. Koch, Endoscopic assessment of early neoplasia in the gastrointestinal tract. EMJ Gastroenterol. 2012; 1: 45-52.

47. Oddsberg, J., Y. Lu, and J. Lagergren, Aspects of esophageal atresia in a population-based setting: incidence, mortality, and cancer risk. Pediatr Surg Int. 2012; 28: 249-57.

48. Sistonen, S.J., et al., Cancer after repair of esophageal atresia: population-based long-term follow-up. J Pediatr Surg. 2008; 43: 602-5.

49. Krug, E., et al., Gastroesophageal reflux and Barrett's esophagus in adults born with esophageal atresia. Am J Gastroenterol. 1999; 94: 2825-8.

50. Levine, D.S., et al., Safety of a systematic endoscopic biopsy protocol in patients with Barrett's esophagus. Am J Gastroenterol. 2000; 95: 1152-7.

51. Hashimoto, C.L., et al., Lugol's dye spray chromoendoscopy establishes early diagnosis of esophageal cancer in patients with primary head and neck cancer. Am J Gastroenterol. 2005; 100: 275-82.

52. Pedersen, R.N., et al., Esophageal atresia: gastroesophageal functional follow-up in 5-15 year old children. J Pediatr Surg. 2013; 48: 2487-95.

53. Catalano, P., et al., Gastroesophageal reflux in young children treated for esophageal atresia: evaluation with $\mathrm{pH}$-multichannel intraluminal impedance. J Pediatr Gastroenterol Nutr. 2011; 52: 686-90.

54. Castilloux, J., D. Bouron-Dal Soglio, and C. Faure, Endoscopic assessment of children with esophageal atresia: Lack of relationship of esophagitis and esophageal metaplasia to symptomatology. Can J Gastroenterol. 2010; 24: 312-6.

55. Kawahara, H., et al., Influence of thoracoscopic esophageal atresia repair on esophageal motor function and gastroesophageal reflux. J Pediatr Surg. 2009; 44: 2282-6.

56. Koivusalo, A., M.P. Pakarinen, and R.J. Rintala, The cumulative incidence of significant gastrooesophageal reflux in patients with oesophageal atresia with a distal fistula--a systematic clinical, pH-metric, and endoscopic follow-up study. J Pediatr Surg. 2007; 42: 3704.

57. Huynh Trudeau, V., et al., Dysphagia among adult patients who underwent surgery for esophageal atresia. Can J Gastroenterol Hepatol. 2015; 29: 91-4.

58. Deurloo, J.A., et al., Adults with corrected oesophageal atresia: is oesophageal function associated with complaints and/or quality of life? Pediatr Surg Int. 2008; 24: 537-41.

59. Deurloo, J.A., et al., Gastroesophageal reflux: prevalence in adults older than 28 years after correction of esophageal atresia. Ann Surg. 2003; 238: 686-9.

60. Koivusalo, A.I., M.P. Pakarinen, and R.J. Rintala, Modern outcomes of oesophageal atresia: single centre experience over the last twenty years. J Pediatr Surg. 2013; 48: 297-303.

61. Burjonrappa, S.C., S. Youssef, and D. St-Vil, What is the incidence of Barrett's and gastric metaplasia in esophageal atresia/tracheoesophageal fistula (EA/TEF) patients? Eur J Pediatr Surg. 2011; 21: 25-9.

62. Schalamon, J., et al., Endoscopic follow-up in esophageal atresia-for how long is it necessary? J Pediatr Surg. 2003; 38: 702-4.

63. Tovar, J.A., et al., Ambulatory 24-hour manometric and pH metric evidence of permanent impairment of clearance capacity in patients with esophageal atresia. J Pediatr Surg. 1995; 30: 1224-31. 


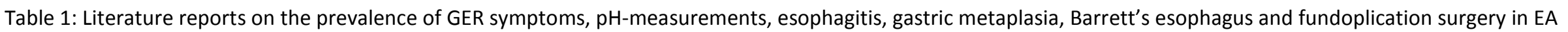
patients: children(A), adults (B) and both children and adults (C)

\begin{tabular}{|c|c|c|c|c|c|c|c|c|c|}
\hline References & $\begin{array}{c}\text { Age } \\
\text { median age in } \\
\text { years (range) }\end{array}$ & $\begin{array}{l}\text { Symptoms of } \\
\text { GER (chest } \\
\text { pain, pyrosis, } \\
\text { regurgitation) } \\
\text { n/N (\%) }\end{array}$ & $\begin{array}{c}\text { Pathological } \\
\text { GER at pH- } \\
\text { measurement } \\
\text { n/N (\%) }\end{array}$ & $\begin{array}{c}\text { Endoscopic } \\
\text { esophagitis } \\
\text { (with erosions) } \\
\text { n/N (\%) }\end{array}$ & $\begin{array}{c}\text { Histological } \\
\text { esophagitis } \\
\text { (moderate- } \\
\text { severe) } \\
\text { n/N (\%) }\end{array}$ & $\begin{array}{c}\text { Gastric } \\
\text { metaplasia in } \\
\text { distal } \\
\text { esophagus } \\
\text { n/N (\%) }\end{array}$ & $\begin{array}{l}\text { Barrett's } \\
\text { esophagus } \\
\text { (intestinal } \\
\text { metaplasia) } \\
\text { n/N (\%) }\end{array}$ & $\begin{array}{c}\text { Fundoplication } \\
\text { surgery } \\
\text { n/N (\%) }\end{array}$ & $\begin{array}{l}\text { Total number of } \\
\text { GERD diagnosis } \\
\text { according to } \\
\text { ACG guidelines }{ }^{1} \\
\text { n/N (\%) }\end{array}$ \\
\hline \multicolumn{10}{|c|}{ A. Studies in children } \\
\hline $\begin{array}{c}\text { Pedersen et al. } \\
2013^{52}\end{array}$ & $10.3(7.1-13.3)$ & $33 / 59$ (55.9) & $32 / 59(54.2)$ & $29 / 59(49.2)$ & $0 / 59(0)$ & $0 / 59(0)$ & $1 / 59(1.7)$ & NR & $32 / 59(54.2)$ \\
\hline $\begin{array}{c}\text { Catalano et al. } \\
2011^{53}\end{array}$ & $1.3(0.3-3.3)$ & $14 / 22(63.6)$ & $10 / 22(45.5)$ & NR & NR & NR & NR & NR & $10 / 22(45.5)$ \\
\hline $\begin{array}{c}\text { Castilloux et al. } \\
2010^{54}\end{array}$ & $7.3(0.4-17.9)$ & $28 / 45(62.2)$ & $9 / 24(37.5)$ & $3 / 45(6.7)^{2}$ & $5 / 45(11.1)^{3}$ & $16 / 45(35.6)$ & $0 / 45(0)$ & $20 / 45(44.4)$ & $20 / 45(44.4)$ \\
\hline $\begin{array}{c}\text { Kawahara et al. } \\
2009^{55}\end{array}$ & $0.1(0.1-0.3)$ & NR & $8 / 16(50.0)$ & NR & NR & NR & NR & $4 / 17(23.5)$ & $8 / 16(50.0)$ \\
\hline $\begin{array}{c}\text { Koivusalo et al. } \\
2007^{56}\end{array}$ & $\begin{array}{c}0.5 \\
1 \\
3 \\
5 \\
10\end{array}$ & NR & $\begin{array}{l}10 / 61(16.4)^{4 \#} \\
20 / 61(32.8)^{4 \#}\end{array}$ & NR & $\begin{array}{c}- \\
24 / 61(39.3)^{5 \#} \\
23 / 52(44.2)^{5 \#} \\
22 / 43(51.2)^{5 \#} \\
12 / 27(44.4)^{5 \#}\end{array}$ & $0 / 61(0)$ & $0 / 61(0)$ & $18 / 61(29.5)$ & $20 / 61(32.8)^{4}$ \\
\hline $\begin{array}{c}\text { Deurloo et al. } \\
2002^{4}\end{array}$ & 0.25 & NR & $53 / 128(41.4)$ & NR & NR & NR & NR & $41 / 128(32.0)$ & $53 / 128(41.4)$ \\
\hline $\begin{array}{c}\text { Lindahl et al. } \\
1993^{41}\end{array}$ & $7.6(2-11)$ & NR & NR & $20 / 39(51.3)$ & $7 / 37$ (18.9) & $3 / 37(8.1)$ & $0 / 39(0)$ & $9 / 39(23.1)$ & $20 / 39$ (51.3) \\
\hline \multicolumn{2}{|c|}{ Total number in children } & $75 / 126(59.5)$ & $112 / 249(45)$ & $45 / 143(31.5)$ & $12 / 141(8.5)$ & $19 / 202(9.4)$ & $1 / 204(0.0)$ & $92 / 290(31.7)$ & $163 / 370(44.1)$ \\
\hline \multicolumn{10}{|c|}{ B. Studies in adults } \\
\hline $\begin{array}{c}\text { Gatzinsky et al. } \\
2015^{24}\end{array}$ & $31(25-40)$ & $11 / 29(37.9)$ & $2 / 15(13.3)$ & $10 / 24(41.7)$ & $11 / 24(45.8)$ & NR & $2 / 24(8.3)$ & NR & $10 / 24(41.7)$ \\
\hline $\begin{array}{c}\text { Huynh-Trudeau } \\
\text { et al. } 2015^{57}\end{array}$ & $25(18-44)$ & $12 / 41(29.3)$ & NR & $6 / 32(18.8)$ & $8 / 12(75)^{6 \#}$ & $6 / 32(18.8)^{6}$ & $4 / 32(12.5)^{6}$ & $15 / 41(36.6)$ & $15 / 41(36.6)$ \\
\hline $\begin{array}{c}\text { Sistonen et al. } \\
2010^{6}\end{array}$ & $36(22-57)$ & $34 / 101(33.7)$ & NR & $8 / 58(13.8)$ & $3 / 101(3.0)$ & $15 / 101(14.9)$ & $6 / 101(5.9)$ & $10 / 101$ (9.9) & $8 / 58(13.8)$ \\
\hline $\begin{array}{c}\text { Deurloo et al. } \\
2008^{58}\end{array}$ & $28.5(18-42)$ & $7 / 21(33.3)$ & $3 / 21(14.3)$ & $3 / 21(14.3)$ & $8 / 19(42.1)$ & NR & NR & $2 / 25(8.0)$ & $3 / 21(14.3)$ \\
\hline $\begin{array}{c}\text { Taylor et al. } \\
2007^{7} \\
\end{array}$ & $33(20-48)$ & $83 / 132$ (62.9) & NR & $36 / 62(58.1)$ & NR & $0 / 62(0)$ & $7 / 62(11.3)$ & 14/132 (10.6) & $36 / 62$ (58.1) \\
\hline $\begin{array}{c}\text { Deurloo et al. } \\
2003^{59} \\
\end{array}$ & $34(28-45)$ & $20 / 38(52.6)$ & NR & $2 / 23(8.7)$ & $11 / 21(52.4)$ & $0 / 21(0)$ & $1 / 21(4.8)$ & $1 / 40(2.5)$ & $2 / 23(8.7)$ \\
\hline $\begin{array}{c}\text { Krug et al. } \\
1999^{49}\end{array}$ & $?(18-26)$ & $13 / 39(33.3)$ & NR & $2 / 34(5.9)$ & $7 / 17(41.2)^{7 \#}$ & $0 / 17(0)^{7 \#}$ & $2 / 17(11.8)^{7 \#}$ & NR & $2 / 34(5.9)$ \\
\hline Biller et al. & $26(22-31)$ & $9 / 12(75)$ & $6 / 9(66.7)$ & NR & NR & $0 / 12(0)$ & $1 / 12(8.3)$ & $2 / 12(16.7)$ & $6 / 9$ (66.7) \\
\hline
\end{tabular}




\begin{tabular}{|c|c|c|c|c|c|c|c|c|c|}
\hline $1987^{8}$ & & & & & & & & & \\
\hline \multicolumn{2}{|c|}{ Total number in adults } & $189 / 413(45.8)$ & $11 / 45(24.4)$ & $67 / 254(26.4)$ & $33 / 165(20)$ & $21 / 228(9.2)$ & $21 / 252(8.3)$ & $44 / 351$ (12.5) & $82 / 272(30.1)$ \\
\hline \multicolumn{10}{|c|}{ C. Studies in children and adults } \\
\hline $\begin{array}{l}\text { Koivusalo et al. } \\
2013^{60}\end{array}$ & $\begin{array}{c}8.8(0.1-21) \\
1\end{array}$ & NR & NR & NR & $\begin{array}{c}- \\
62 / 130(47.7)^{5 \#}\end{array}$ & NR & NR & $37 / 130(28.5)$ & $37 / 130(28.5)$ \\
\hline $\begin{array}{l}\text { Schneider et al. } \\
2013^{9}\end{array}$ & $16.6(15-19)$ & NR & NR & NR & NR & $36 / 88$ (40.9) & $1 / 88(1.1)$ & NR & no valuable data \\
\hline $\begin{array}{l}\text { Burjonrappa et } \\
\text { al. } 2011^{61}\end{array}$ & $6.6(0.6-19)$ & NR & $21 / 33(63.6)$ & $4 / 38(10.5)$ & NR & $11 / 38(28.9)$ & $1 / 38(2.6)$ & $17 / 51(33.3)$ & $21 / 33(63.6)$ \\
\hline $\begin{array}{c}\text { Deurloo et al. } \\
2005^{43}\end{array}$ & $17(10-26)$ & $28 / 86(32.6)$ & NR & $13 / 49(26.5)$ & $15 / 40(37.5)$ & $3 / 40(7.5)$ & $0 / 40(0)$ & 19/92 (20.7) & $13 / 49(26.5)$ \\
\hline $\begin{array}{l}\text { Schalamon et } \\
\text { al. } 2003^{62}\end{array}$ & $10.3(0.5-19.1)$ & NR & NR & NR & $10 / 74(13.5)$ & $13 / 74(17.6)$ & $0 / 74(0)$ & $21 / 74(28.4)$ & $21 / 74(28.4)$ \\
\hline $\begin{array}{c}\text { Tomaselli et al. } \\
2003^{25}\end{array}$ & $15.8(7-28)$ & $13 / 26(50)$ & $2 / 12(16.7)$ & $3 / 15(20)$ & NR & NR & NR & NR & $3 / 15(20)$ \\
\hline $\begin{array}{c}\text { Somppi et al. } \\
1998^{42}\end{array}$ & $12.6(3.5-30)$ & $8 / 43(18.6)$ & 9/41 (22.0) & $1 / 31(3.2)$ & $7 / 35(20)$ & $2 / 35(5.7)$ & $0 / 35(0)$ & $5 / 52(9.6)$ & 9/41 (22.0) \\
\hline $\begin{array}{c}\text { Tovar et al. } \\
1995^{63}\end{array}$ & $17.1(9-26)$ & $13 / 22(59.1)^{8}$ & $12 / 22(54.5)^{8}$ & NR & NR & NR & NR & $0 / 22(0)^{8 \#}$ & $12 / 22(54.5)^{8}$ \\
\hline \multicolumn{2}{|c|}{$\begin{array}{l}\text { Total number in children and } \\
\text { adults }\end{array}$} & $326 / 716(45.5)$ & $167 / 402(41.5)$ & $133 / 530(25.1)$ & $77 / 455$ (16.9) & $105 / 695(15.1)$ & $24 / 731(3.3)$ & $\begin{array}{l}235 / 1040 \\
(22.6)\end{array}$ & $360 / 1006(35.8)$ \\
\hline
\end{tabular}

EA: esophageal atresia, GER: gastroesophageal reflux, GERD: gastroesophageal reflux disease, NR: not (clearly) reported

\# To exclude selection bias, these numbers are not used to calculate the total prevalence of the features, see below the different reasons.

${ }^{1}$ GERD diagnosis defined as: fundoplication surgery performed, $\mathrm{pH}$-measurement positive or endoscopic esophagitis (according to the ACG Guidelines).

${ }^{2}$ No official classification used for endoscopic grading of esophagitis.

${ }^{3}$ Histological diagnosis of 3 biopsies was unspecified.

${ }^{4}$ Fundoplication surgery and $\mathrm{pH}$-measurement.

${ }^{5}$ Fundoplication surgery, $\mathrm{pH}$ measurement, and histological esophagitis (moderate-severe).

${ }^{6}$ Biopsies ( $\left.n=12\right)$ taken in presence of endoscopic abnormalities: Barrett's esophagus $(n=10)$ and/or esophagitis $(n=6)$.

${ }^{7}$ Biopsies ( $\left.n=17\right)$ taken in presence of esophagitis and/or Barrett's epithelium ( $\left.n=8\right)$ or normal mucosa $(n=9)$.

8 Patients with a history of fundoplication surgery or severe/obvious symptoms were excluded from this study. 
Table 2: Reported esophageal cancer in EA patients $(n=8)$

\begin{tabular}{|c|c|c|c|c|c|c|}
\hline References & $\begin{array}{l}\text { Gender, age, type of } \\
\text { EA, type of surgery }\end{array}$ & $\begin{array}{l}\text { Type and location of } \\
\text { esophageal cancer }\end{array}$ & GERD & $\begin{array}{l}\text { Postsurgical } \\
\text { esophageal stenosis } \\
\text { and dilatations }\end{array}$ & $\begin{array}{c}\text { Esophagitis and } \\
\text { Barrett's esophagus }\end{array}$ & $\begin{array}{c}\text { Habits of alcohol and } \\
\text { smoking }\end{array}$ \\
\hline $\begin{array}{l}\text { Adzick et al. } \\
1989^{14}\end{array}$ & $\begin{array}{l}\text { Female, } 20 \text { years } \\
\text { Gross type C, primary } \\
\text { repair }\end{array}$ & $\begin{array}{l}\text { EAC, at GEJ with } \\
\text { extension to lower } \\
\text { esophagus and cardia }\end{array}$ & No & $\begin{array}{l}\text { Yes, multiple } \\
\text { dilatations }\end{array}$ & No & No \\
\hline $\begin{array}{c}\text { Deurloo et al. } \\
2001^{12}\end{array}$ & $\begin{array}{l}\text { Male, } 38 \text { years } \\
\text { Gross type C, primary } \\
\text { repair }\end{array}$ & $\begin{array}{l}\text { ESCC, at } 2 \mathrm{~cm} \text { distal of } \\
\text { the anastomosis }\end{array}$ & Not reported & $\begin{array}{l}\text { Yes, no dilatation } \\
\text { possible, resection of } \\
\text { stenosis }\end{array}$ & Not reported & Alcohol and smoking \\
\hline $\begin{array}{l}\text { Alfaro et al. } \\
2005^{15}\end{array}$ & $\begin{array}{l}\text { Female, } 46 \text { years } \\
\text { Gross type E, primary } \\
\text { TEF repair }\end{array}$ & $\mathrm{EAC}$, in $\mathrm{BE}(18-35 \mathrm{~cm})$ & Since age of 5 years & $\begin{array}{l}\text { Yes, multiple } \\
\text { dilatations }\end{array}$ & Barrett's esophagus & No \\
\hline $\begin{array}{c}\text { Pultrum et al. } \\
2005^{16}\end{array}$ & $\begin{array}{l}\text { Female, } 22 \text { years } \\
\text { Gross type C, primary } \\
\text { repair (high tension } \\
\text { with post-operative } \\
\text { mediastinal leakage } \\
\text { and mediastinitis) }\end{array}$ & EAC, at anastomosis & $\begin{array}{l}\text { Hiatus hernia with } \\
\text { GER and aspirations } \\
\text { Gastrostomy at age of } \\
3 \text { years and Nissen } \\
\text { fundoplication at age } \\
\text { of } 16 \text { years }\end{array}$ & $\begin{array}{l}\text { Yes, multiple } \\
\text { dilatations }\end{array}$ & Esophagitis & Not reported \\
\hline $\begin{array}{c}\text { Jayasekera et al. } \\
2012^{13}\end{array}$ & $\begin{array}{l}\text { Female, } 44 \text { years } \\
\text { Gross type C, primary } \\
\text { repair }\end{array}$ & $\begin{array}{l}\text { ESCC, at anastomosis } \\
(23 \mathrm{~cm}) \\
- \text { Metastasis frontal } \\
\text { lobe and mediastinum }\end{array}$ & Yes & No & Esophagitis & $\begin{array}{l}\text { Smoking at age 15-19 } \\
\text { years }\end{array}$ \\
\hline $\begin{array}{l}\text { Jayasekera et al. } \\
2012^{13}\end{array}$ & $\begin{array}{l}\text { Female, } 46 \text { years } \\
\text { Gross type C, primary } \\
\text { repair }\end{array}$ & $\begin{array}{l}\text { ESCC, mid-esophageal } \\
\text { at } 20-28 \mathrm{~cm} \text { with } \\
\text { reactive mediastinal } \\
\text { and subcardinal lymph } \\
\text { nodes }\end{array}$ & Not reported & $\begin{array}{l}\text { Yes, multiple } \\
\text { dilatations }\end{array}$ & Not reported & No \\
\hline $\begin{array}{l}\text { Jayasekera et al. } \\
2012^{13}\end{array}$ & $\begin{array}{l}\text { Male, } 46 \text { years } \\
\text { Gross type C, delayed } \\
\text { primary repair (day } \\
\text { 49) }\end{array}$ & $\begin{array}{l}\text { ESCC, in BE }(19-21 \mathrm{~cm}) \\
\text { with reactive para- } \\
\text { aortic lymph node }\end{array}$ & $\begin{array}{l}\text { Hiatus hernia with } \\
\text { GER and aspirations } \\
\text { Gastrostomy at age of } \\
1 \text { year and Allison } \\
\text { repair at age } 4 \text { years }\end{array}$ & $\begin{array}{l}\text { Yes, twice resection of } \\
\text { stenosis and multiple } \\
\text { dilatations }\end{array}$ & $\begin{array}{l}\text { Esophagitis and a } \\
16 \mathrm{~cm} \text { long BE with low } \\
\text { grade dysplasia }\end{array}$ & Alcohol and smoking \\
\hline $\begin{array}{l}\text { Jayasekera et al. } \\
2012^{13}\end{array}$ & $\begin{array}{l}\text { Male, } 44 \text { years } \\
\text { Gross type } C \text {, primary } \\
\text { repair, recurrent TEF }\end{array}$ & $\begin{array}{l}\text { ESCC, tumor mass } \\
\text { eroding through } \\
\text { sternum and ribs }\end{array}$ & Not reported & $\begin{array}{l}\text { Yes, resection of } \\
\text { stenosis, multiple } \\
\text { dilatations }\end{array}$ & Not reported & Not reported \\
\hline
\end{tabular}

BE: Barrett's esophagus, EA: esophageal atresia, EAC: esophageal adenocarcinoma, ESCC: esophageal squamous cell carcinoma, GEJ: gastroesophageal junction, GER:

gastroesophageal reflux, GERD: gastroesophageal reflux disease, TEF: tracheo esophageal fistula 